\title{
RESPON SAWI (Brassica juncea L) TERHADAP POC AIR LIMBAH BUDIDAYA LELE PLUS (ALBL PLUS)
}

\author{
Firman dan Farida Aryani \\ (Dosen Fakultas Pertanian Universitas Hazairin Bengkulu)
}

\begin{abstract}
ABSTRAK
Produksi sayuran termasuk Sawi (Brassica juncea L) organik masyarakat kita perlu ditingkatkan diantaranya melalui pemberian pupuk organik cair. Pupuk Organik Cair Air Limbah Budidaya Lele kaya nitrogen (POC ALBL-PLUS) merupakan pupuk organik cair kaya hara nitrogen, sehingga sangat berpotensi untuk diberikan pada tanaman sayuran khususnya sawi. Penelitian respon sawi (Brassica juncea) terhadap pupuk organik cair air limbah budidaya lele kaya nitrogen (POC ALBL-PLUS) perlu dilakukan untuk memperoleh rekomendasi aplikasi POC ALBL-PLUS yang terbaik pada tanaman sawi. Penelitian menggunakan Rancangan Acak Lengkap Faktor Tunggal dengan 6 ulangan. Aplikasi POC ALBL-PLUS sebagai perlakuan adalah; $\mathrm{A}=0,0 \mathrm{~g} / \mathrm{l}$ (kontrol), $\mathrm{B}=5 \mathrm{~g} / \mathrm{l}$ tiap 5 hari sekali, $\mathrm{C}=5 \mathrm{~g} / \mathrm{l}$ tiap 10 hari sekali, $\mathrm{D}=10$ $\mathrm{g} / \mathrm{l}$ tiap 5 hari sekali, $\mathrm{E}=10 \mathrm{~g} / \mathrm{l}$ tiap 10 hari sekali, $\mathrm{F}=15 \mathrm{~g} / \mathrm{l}$ tiap 5 hari sekali, $\mathrm{G}=15 \mathrm{~g} / \mathrm{l}$ tiap 10 hari sekali, $\mathrm{H}=20 \mathrm{~g} / \mathrm{l}$ tiap 5 hari sekali, $\mathrm{I}=20 \mathrm{~g} / \mathrm{l}$ tiap 10 hari sekali. Aplikasi POC ALBLPLUS tidak berpengaruh nyata terhadap tinggi tanaman dan umur berbunga, berpengaruh nyata terhadap jumlah daun serta berpengaruh sangat nyata terhadap berat berangkasan basah tanaman caesim (Brassica juncea L). Aplikasi POC ALBL_PLUS $5 \mathrm{~g} / \mathrm{l}$ dengan waktu pemberian tiap lima hari sekali (perlakuan B) meningkatkan jumlah daun dua kali lebih banyak dan berat berangkasan basah enam kali lebih berat dibandingkan tanpa aplikasi POC ALBL-PLUS (kontrol).
\end{abstract}

Kata Kunci : POC, Nitrogen, Sawi

\section{BAB I PENDAHULUAN}

Sawi (Brassica juncea L) dikenal juga dengan nama Caesim adalah merupakan salah satu tanaman sayuran yang cukup populer dan bernilai ekonomis tinggi. Sayuran ini sangat digemari oleh masyarakat, karena selain rasanya yang khas dan enak, juga sangat bermanfaat bagi manusia karena mengandung banyak vitamin, karbohidrat dan mineral yang sangat dibutuhkan oleh tubuh manusia (Zulkarnain, 2010).

Menurut Kementerian Pertanian Konsumsi tingkat konsumsi buah dan sayuran masyarakat kita baru sekitar 40 kg/kapita/tahun. Angka ini jauh lebih rendah atau dibawah standar kecukupan pangan terhadap buah dan sayur yang ditetapkan oleh FAO yaitu sekitar 65,75 $\mathrm{kg} / \mathrm{kapita} / \mathrm{sayuran}$ (anonimous, 2012).

Rendahnya tingkat konsumsi sayuran nasional berkaitan erat dengan masih rendahnya produksi sayuran yang dihasilkan oleh petani kita. Produksi Sawi negara kita pada tahun 2011 sekitar 580,969 ton. Salah satu usaha untuk meningkatkan produksi Sawi (Brassica juncea L) khususnya sawi organik adalah dengan pemberian pupuk terutama sekali pupuk organik, karena penggunaan pupuk an organik dalam jangka panjang justeru dapat menurunkan produksi tanaman.

Pupuk organik cair air limbah budidaya lele kaya nitrogen (POC ALBLPLUS), merupakan pupuk organik yang berasal dari Air Limbah Budidaya Lele yang diperkaya dengan alga Chaetomorpha sp. Kandungan hara nitrogen di dalam POC 
ALBL-PLUS ini berkisar 10,024-12,117 persen, sedangkan kadar hara phosfor 0,130 - 2,821 persen dan kalium 0,442-0,528 persen (Firman dan Pardiansyah., 2017). Kadar hara nitrogen yang terkandung di dalam POC ALBL-PLUS jauh di atas ketentuan Permentan 70 tahun 2011 yang mensyaratkan nitrogen di dalam pupuk organik cair berkisar 3-6 persen.

Permasalahan dalam pemberian POC ALBL-PLUS adalah belum adanya rekomendasi aplikasi pupuk ini pada tanaman sayuran, terutama sekali tanaman sawi (Brassica juncea L). Untuk itu penelitian dengan topik Respon sawi (Brassica juncea $\mathrm{L}$ ) terhadap pupuk organik cair air limbah budidaya kaya nitrogen (POC ALBL-PLUS) perlu dilakukan untuk memperoleh rekomendasi aplikasi pupuk organik cair tersebut pada tanaman sayuran khususnya sawi (Brassica juncea L) yang dibudidayakan secara organik.

\section{BAB II BAHAN DAN METODE}

Penelitian ini akan dilaksanakan di Jalan Kapuas 6B No. 47C Kelurahan Padang Harapan, Kecamatan Gading Cempaka, Kota Bengkulu. Adapun pelaksanaan penelitian direncanakan dari bulan Maret - Agustus 2017

Alat yang digunakan dalam penelitian ini adalah drum sedang, derigen 10 liter, ember, centong, corong plastik, alat takar, blender, pH meter, kamera, saringan, cangkul, sabit dan alat tulis. Adapun bahan yang digunakan adalah sampel air limbah budidaya Lele, alga Chaetomorpha, kapur pertanian, EM-4, polibag, kertas label, benih sawi (Brassica juncea L), paranet

Penelitian menggunakan Rancangan Acak Lengkap faktor tunggal dengan Perlakuan penelitian aplikasi POC ALBLPLUS sebagai berikut: $\mathrm{A}=0,0 \mathrm{~g} / \mathrm{l}$ (kontrol), $\mathrm{B}=5 \mathrm{~g} / \mathrm{l}$ tiap 5 hari sekali, $\mathrm{C}=$ $5 \mathrm{~g} / 1$ POC ALBL-PLUS tiap 10 hari sekali, $\mathrm{D}=10 \mathrm{~g} / \mathrm{l}$ POC ALBL-PLUS tiap 5 hari sekali, $\mathrm{E}=10 \mathrm{~g} / \mathrm{l}$ POC ALBL-PLUS tiap
10 hari sekali, $\mathrm{F}=15 \mathrm{~g} / \mathrm{l}$ POC ALBLPLUS tiap 5 hari sekali, $\mathrm{G}=15 \mathrm{~g} / \mathrm{l}$ POC ALBL-PLUS tiap 10 hari sekali, $\mathrm{H}=20 \mathrm{~g} / \mathrm{l}$ POC ALBL-PLUS tiap 5 hari sekali, I = $20 \mathrm{~g} / \mathrm{l}$ POC ALBL-PLUS tiap 10 hari sekali. Tiap perlakuan di ulang sebanyak 6 kali, sehingga diperoleh 54 unit percobaan. Data yang diperoleh dianalisis dengan sidik ragam dan bila terdapat pengaruh perlakuan, analisis dilanjutkan dengan uji Duncan New Multiple Range Test pada taraf 5 dan atau 1 persen.

Contoh air limbah budidaya Lele diambil di tiga lokasi yang telah ditentukan. Pengambilan contoh air limbah dilakukan pada kolam pembesaran Lele sebanyak lebih kurang 20 liter. Alga atau ganggang diperoleh dari alam. Selanjutnya alga tersebut dikering anginkan, kemudian dihaluskan. Proses pembuatan pupuk organik cair diawali dengan pencampuran Air Limbah Budidaya Lele dengan tepung alga Chaetomorpha sp dengan perbandingan 9 : 1, kemudian cairan difermentasi dengan EM-4.

Lokasi percobaan dipilih tanah dengan topografi datar dan dekat sumber air. Selanjutnya lahan dibersihkan dari rumput dan kotoran. Rumah naungan dibuat dari bahan kayu dengan ukuran $3 \mathrm{~m}$ x $5 \mathrm{~m}$. Kemudian pada bagian atas ditutupi dengan paranet. Selanjutnya rumah naungan dipagari dengan waring. Media Tanam menggunakan polibag ukuran lebih kurang $5 \mathrm{~kg}$, Polibag diisi tanah top soil yang diperoleh disekitar lokasi penelitian. Benih yang sudah disiapkan ditanam ke polibag sebanyak 4 benih tiap polibag. Setelah tanaman tumbuh, tiap polibag ditinggal 1 tanaman. Pemupukan tanaman dilakukan sesuai perlakuan sedangkan penyiraman dilakukan setiap hari tergantung kondisi tanaman. Panen tanaman Sawi dilakukan pada umur 40-70 hari setelah tanam. Peubah yang diamati meliputi Tinggi Tanaman $(\mathrm{cm})$, Jumlah Daun (helai) dan Berat Berangkasan Basah (gram). 


\section{BAB III \\ HASIL DAN PEMBAHASAN}

\subsection{HASIL}

Berdasarkan hasil sidik ragam aplikasi pemupukan POC ALBL-PLUS tidak berpengaruh nyata terhadap tinggi tanaman dan umur berbunga, berpengaruh nyata terhadap jumlah daun serta berpengaruh sangat nyata terhadap berat berangkasan basah Caesim (Brassica juncea). Grafik 1 dan 2 memperlihatkan bahwa aplikasi POC ALBL-PLUS 5 gram perliter tiap 5 hari (perlakuan B) menghasilkan tinggi tanaman tertinggi dan umur berbunga terlama dibandingkan dengan tanpa POC ALBLPLUS (perlakuan A) dan aplikasi POC ALBL-PLUS (C, D, E, F, G, H dan I). Namun demikian secara statistik tinggi tanaman dan umur berbunga tidak menunjukan perbedaan yang nyata diantara perlakuan.

Tabel 1. Menunjukkan jumlah daun terbanyak hasil dari aplikasi POC ALBLPLUS 5 gram perliter tiap 5 hari (perlakuan B) berbeda nyata dibandingkan dengan tanpa aplikasi POC ALBL-PLUS (perlakuan A), namun tidak berbeda nyata dibandingkan dengan aplikasi POC ALBLPLUS lainnya (perlakuan C, D, E, F, G, H dan I). Penambahan konsentrasi aplikasi POC ALBL-PLUS di atas 5 gram perliter cenderung akan menurunkan jumlah daun yang dihasilkan. Berat berangkasan basah hasil aplikasi POC ALBL-PLUS 5 gram perliter yang diberikan tiap 5 hari (perlakuan B) berbeda nyata dibandingkan dengan tanpa aplikasi POC ALBL-PLUS (perlakuan A) dan aplikasi POC ALBL-PLUS 10 gram perliter tiap 5 hari (perlakuan D), namun tidak berbeda nyata dibandingkan aplikasi POC ALBL-PLUS lainnya (perlakuan C, E, F, G, H dan I). Aplikasi POC ALBL-PLUS 5 gram dengan pemberian tiap 5 hari mampu meningkatkan berat berangkasan basah dari 43,78 gram pertanaman (perlakuan A) menjadi 261, 12 gram pertanaman (perlakuan B). Pemberian POC ALBLPLUS 5 gram perliter tiap 5 hari (perlakuan
B) menghasilkan berat berangkasan tertinggi dibanding berat berangkasan basah perlakuan lainnya. Seperti halnya jumlah daun, penambahan konsentrasi POC ALBLPLUS lebih dari 5 gram perliter (perlakuan B) juga cenderung menurunkan berat berangkasan basah Sawi (Tabel 1.)

\subsection{PEMBAHASAN}

Pupuk Organik Cair Air Limbah Budidaya Lele plus (POC ALBL-PLUS) merupakan pupuk organik berbentuk cair yang kaya hara makro terutama nitrogen. Kandungan nitrogen dalam pupuk ini ratarata berkisar 5,36 persen sampai 10,93 persen (Firman dan Dedi Pardiansyah, 2017). Pemberian pupuk organik cair ALBL-PLUS meningkatkan pertumbuhan caisim (Brassica juncea), hal ini terlihat dari jumlah daun bertambah secara signifikan dan berat berangkasan basah meningkat sangat signifikan dibanding tanpa pemberian POC ALBL-PLUS (perlakuan A). Demikian pula tanaman juga bertambah tinggi, walaupun secara statistik tidak berbeda nyata dibanding tanpa aplikasi POC ALBL-PLUS (perlakuan A). Menurut Setymidjaya (1986) menyatakan bahwa hara nitrogen berperan merangsang pertumbuhan vegetatif tanaman. Pemberian pupuk organik kaya nitrogen pada tanah akan menyebabkan sifat fisik tanah dan ketersedian hara tanaman semakin baik, sehingga tersedianya air dan hara dipermukaan akar akan mengoptimal akar menyerap hara serta kemudian mempengaruhi proses fotosintesis. Proses fotosintesis sangat membutuhkan zat hijau daun tanaman. Ketersedian unsur nitrogen dalam jumlah yang cukup dibutuhkan untuk pembentukan zat hijau daun, mempengaruhi proses metabolisme tanaman terutama sayuran dalam pembentukan dan pertumbuhan organ-organ tanaman seperti batang, daun dan akar. Batang tumbuh lebih tinggi, jumlah daun bertambah dan sistem perakaran lebih luas (Hakim et al., 1986, 
Noverita, 2005, Tambunan, 2008 dan Soemarno, 2013). Pada tanaman yang dipanen bagian vegetatif, seperti sayuran lebih tanggap terhadap pemberian pupuk kaya nitrogen dibandingkan unsur hara lainnya. Selanjutnya hasil penelitian ini sejalan dengan penelitian Atari et al., (2017), yang menyatakan bahwa pemberian kompos atau pupuk organik berpengaruh nyata terhadap tinggi tanaman, jumlah daun dan bobot segar total Caesim (Brassica juncea ). Bahkan pertumbuhan dan berat produksi Caesim yang diperoleh dari penelitian ini relatif lebih baik dibanding penelitian sejenis seperti Ghatot Subrata dan Erningpraja Martha, (2017) dan Sastro et a.l, (2015). Hal ini disebabkan oleh tingginya kadar Nitrogen yang terdapat dalam POC ALBL-PLUS. Pemupukan dengan POC ALBL-PLUS selain mempengaruhi pertumbuhan vegetatif, juga perkembangan tanaman. Hal ini terlihat pada umur berbunga tanaman Caesim yang cenderung semakin lama dengan semakin bertambahnya jumlah nitrogen yang diberikan (grafik 2.). Menurut Novizan (2002), Dosis pupuk yang terus bertambah dapat menyebabkan kelebihan unsur hara yang ditandai warna daun yang terlalu hijau, tanaman rimbun dengan daun dan pembungaan lebih lama. Demikian pula menurut Sutedjo, (2002), Nitrogen memang merupakan unsur utama yang dibutuhkan untuk pertumbuhan vegetatif tanaman daun batang dan akar, akan tetapi jika berlebih dapat menghambat pembungaan dan pembuahan pada tanaman.

\section{BAB IV KESIMPULAN}

\footnotetext{
Kombinasi Konsentrasi dan waktu aplikasi POC ALBL-PLUS tidak berpengaruh nyata terhadap tinggi tanaman dan umur berbunga, berpengaruh nyata terhadap jumlah daun serta berpengaruh sangat nyata terhadap berat berangkasan basah tanaman Caesim (Brassica juncea L). Aplikasi konsentrasi 5 gram perliter dengan
}

waktu pemberian tiap lima hari sekali (Perlakuan B) memberikan jumlah daun dan berat berangkasan basah tertinggi dan berbeda dibanding perlakuan lainnya.

\section{DAFTAR PUSTAKA}

Anonimous, 2012. Produksi Sayuran di Indonesia.http://www.bps.go.id

Firman dan Pardiansyah, D, 2017. Pengayaan Air Limbah Budidaya Lele sebagai Bahan Pembuatan POC Berkualitas. Lembaga Penelitian dan Pengabdian Kepada Masyarakat UNIHAZ. Laporan Penelitian. 28 halaman.

Ghatot Subrata, B.A., \& B. Erningpraja Martha, 2017. Respon Pertumbuhan dan Hasil Tiga varietas Caesim terhadap Pemberian Pupuk Organik cair BIOMETHAGREEN. Jurnal Floratek 12(2): 90-100)

Hakim, N.,M.Y. Nyakpa, A.M., Lubis, S.G., Nugroho, M.R., Saul, M.H., Diha, G.B Hong \& H.H. Bailey. 1986. Dasar-dasar Ilmu Tanah. Universitas lampung Press. Lampung.

Nindya Atari, Wisnu Eko Murdiono dan koesrihardi. 2017. Pengaruh Pupuk Kompos UB dan Pupuk Nitrogen terhadap Pertumbuhan dan hasil tanaman Sawi Bunga (Brasssica Juncea L) jurnal produksi Tanaman. 5(12) : 1936-1941

Noverita. V.S., 2005. Pengaruh Pemberian Nitrogen dan Kompos terhadap Komponen Pertumbuhan Tanaman Lidah Buaya(Aloe vera. Jurnal Penelitian Bidang Ilmu Pertanian. 3(3)95-105

Novizan, 2002. Petunjuk Pemupukan yang efektif. Agromedia Pustaka Jakarta.

Seprita Lidar dan Hadi Suwarno, 2015 Uji Beberapa pupuk Organik terhadap 
tanaman Caesim, jurnal Ilmiah Pertanian Volume 11 N0. 2 tahun 2015

Soemarno. 2013. Dasar Ilmu Tanah: Tanah Inceptisols. Fakultas Pertanian UB. Malang Sutedjo, M.M. 2002. Pupuk dan Cara Pemupukan. PT. Bina Angkasa. Jakarta.

Tambunan.W.A. 2008. Kajian Sifat Fisik dan Kimia Tanah Hubungan dengan Produksi Kelapa sawit PTPN II. Tesis Sekolah Pasca Sarjana Universitas Sumatera Utara. Medan
Yudi Sastro, Erna P. Astuti, Ikrarwati, dan Susi Sutardi, 2015. Efektivitas Pupuk Organik Cair Hasil Fermentasi Limbah Ikan Pada Caisim dan Selada Skala Lapangan. Prosiding Seminar Nasional Swasembada Pangan Politeknik Negeri Lampung 29 April 2015 ISBN 978-602-70530-2-1 halaman 232-238

Zulkarnain, 2010. Dasar-Dasar Hortikultura. Bumi Aksara. Jakarta 
